\title{
Hubungan Kadar Kolesterol Total dengan Tekanan Darah pada Masyarakat Jatinangor
}

\author{
Mariya Ulfah ${ }^{1}$, Hadyana Sukandar ${ }^{2}$, Afiatin $^{3}$ \\ ${ }^{1}$ Fakultas Kedokteran Universitas Padjadjaran \\ ${ }^{2}$ Departemen Ilmu Kesehatan Masyarakat, Fakultas Kedokteran Universitas Padjadjaran \\ ${ }^{3}$ Departemen Ilmu Penyakit Dalam, Fakultas Kedokteran Universitas Padjadjaran
}

\begin{abstract}
Abstrak
Hipertensi adalah salah satu penyakit yang banyak menyebabkan kematian dan komplikasi yang berkaitan dengan penyakit kardiovaskuler. Prevalensi hipertensi di Indonesia sebesar $25,8 \%$. Salah satu faktor yang memengaruhi kejadian hipertensi adalah tingginya kadar kolesterol dalam darah (hiperkolesterolemia). Penelitian ini bertujuan untuk mengetahui hubungan antara kadar kolesterol total dengan tekanan darah pada masyarakat Jatinangor. Metode penelitian ini merupakan observasional analitik korelasional dengan rancangan potong lintang. Populasi penelitian adalah masyarakat di kecamatan Jatinangor dari tiga desa yaitu Cilayung, Cipacing dan Hegarmanah. Data diperoleh dari penelitian "Epidemiologi Hipertensi dan Albuminuria di Jatinangor pada tahun 2014". Penelitian dilaksanakan pada bulan Agustus hingga November 2016. Subjek yang terlibat dalam penelitian ini adalah 107 responden. Terdiri dari 75 perempuan $(70,1 \%$ ) dan 32 laki-laki $(29,9 \%)$, dengan rentang usia 23-82 tahun. Nilai tengah tekanan darah sistolik dan diastolik adalah $144 \mathrm{mmHg}$ (rentang= 98-224 mmHg) dan $85 \mathrm{mmHg}$ (rentang= 58-139 mmHg), nilai tengah kadar kolesterol total adalah $189 \mathrm{mg} / \mathrm{dL}$ (rentang=110-310 mg/dL). Hasil analisis korelasi rank-Spearman diperoleh hubungan antara kadar kolesterol total dengan tekanan darah sistolik meskipun menunjukkan korelasi lemah $(r=0,297 ; p=0,004)$; dan dengan tekanan darah diastolik $(r=0,145 ; p=0,136)$. Simpulan secara statistik diperoleh hubungan yang bermakna dengan nilai korelasi lemah antara kadar kolesterol total dengan tekanan darah sistolik.
\end{abstract}

Kata Kunci : Kadar Kolesterol Total, Tekanan Darah Diastolik, Tekanan Darah Sistolik

\section{Correlation of Total Cholesterol Level and Blood Pressure in Jatinangor}

\begin{abstract}
Hypertension is known as one of causes of death and also related to cardiovascular complication. The prevalence of hypertension in Indonesia is $25.8 \%$. One of the factors influencing the occurence of hypertension is hypercholesterolemia. This study was conducted in order to discover the correlation between total cholesterol level and blood pressure in the residents of Jatinangor. Method an observational, analytical study was conducted. The study design was cross-sectional, and the study population was residents of Cilayung, Cipacing, and Hegarmanah district in Jatinangor. Secondary data were obtained from previous study entitled "Epidemiology of Hypertension and Albuminuria in Jatinangor at 2014". This study was conducted in August-November 2016. Spearman's rank test was conducted to correlate total cholesterol level with both sistolic and diastolic blood pressure. From the total of 107 subject, 75 were female (70.1\%), 32 were male (29.9\%) with range age was 23-82 years old. Median sistolic blood pressure was $144 \mathrm{mmHg}$ (range $=98-224 \mathrm{mmHg}$ ) and diastolic blood pressure was 85 $\mathrm{mmHg}$ (range $=58-139 \mathrm{mmHg}$ ). Median cholesterol level was $189 \mathrm{mg} / \mathrm{dL}$ (range $=110-310 \mathrm{mg} / \mathrm{dL}$ ). There was significant correlation between total cholesterol level and sistolik blood pressure whereas has weak correlation $(r=0.297 ; p=0.004)$, while the correlation with diastolic blood pressure was not significant $(r=0.145 ; p=0.136)$. Statistically significant weak correlation was found between total cholesterol level and sistolic blood pressure.
\end{abstract}

Keywords : Diastolic Blood Pressure, Sistolic Blood Pressure, Total cholesterol level

Korespondensi:

Mariya Ulfah

Fakultas Kedokteran Universitas Padjadjaran

Jl. Raya Bandung-Sumedang KM 21 Jatinangor, Sumedang

Mobile : 085724921898

Email : mariyaulfah39@gmail.com 


\section{Pendahuluan}

Penyakit tidak menular (PTM) adalah suatu penyakit kronis yang tidak dapat ditularkan dari satu orang ke orang lainn yang pada umumnya berkembang lambat. Diperkirakan pada tahun 2030 akan ada kenaikan jumlah PTM seperti kanker, jantung, diabetes melitus dan paru obstruktif kronik serta penyakit kronik lainnya. Peningkatan dihubungkan dengan adanya faktor risiko yang juga meningkat yaitu perubahan gaya hidup, pertumbuhan populasi dan peningkatan usia harapan hidup. Menurut riset kesehatan dasar (Riskesdas) tahun 2007 dan survei kesehatan rumah tangga (SKRT) tahun 1995 dan 2001 , terjadi peningkatan angka kematian akibat PTM dan diperkirakan akan terus meningkat. Menurut profil PTM World Health Organization (WHO) tahun 2011, di Indonesia pada tahun 2008 terdapat 582.300 laki-laki dan 481.700 perempuan meninggal karena PTM.

Tekanan darah tinggi adalah salah satu bentuk penyakit tidak menular yang dapat menyebabkan kematian dan komplikasi terutama berhubungan dengan sistem kardiovaskuler. Pada awal fase hipertensi jarang menyebabkan gejala sehingga jarang sekali terdiagnosis, akibatnya orang dengan hipertensi datang ke pelayanan kesehatan dengan keadaan tekanan darah yang tidak terkontrol dan biasanya hipertensi sudah dibarengi dengan komplikasi, oleh karena itu hipertensi juga disebut sebagai "silent killer" karena gejalanya yang tidak terdeteksi pada awal fase. Berdasarkan data dari WHO pada tahun 2013, terdapat 17 juta orang meninggal pertahun dan satu-pertiganya atau 9,4 juta orang merupakan komplikasi penyakit hipertensi. Prevalensi hipertensi di Indonesia mencapai $25,8 \%$. Provinsi jawa barat merupakan salah satu dari 5 provinsi dengan prevalensi hipertensi tertinggi yaitu $29,4 \%$ dan persentase perempuan lebih tinggi dari laki-laki (28,8\% dan 22,8\%). ${ }^{1}$ Prevalensi hipertensi di Jatinangor sebesar $37.8 \%$, prevalensi tertinggi terjadi pada grup umur $>70$ tahun, perempuan dan bertempat tinggal di sub-urban. Prevalensi komplikasi yang disebabkan hipertensi sebanyak $33.9 \%$, komplikasi tertinggi adalah serangan jantung dan stroke. ${ }^{2}$

Faktor yang bermacam-macam memengaruhi terjadinya hipertensi, baik dari faktor genetik, faktor sosioekonomik seperti globalisasi, persebaran populasi atau kepadatan penduduk, usia, pendapatan, pendidikan dan tempat tinggal, serta faktor perilaku yang tidak sehat seperti mengkonsumsi makanan yang mengandung garam, lemak atau makanan berkolesterol tinggi, sedikit beraktifitas, mengkonsumsi alkohol dan merokok. ${ }^{1,3,4,5}$ Kolesterol diperlukan dalam tubuh sebagai bahan dasar dalam pembentukan hormon seks, kortikosteroid, asam empedu, dan vitamin D. Namun kolesterol pun dapat berperan dalam terjadinya suatu penyakit, apabila jumlah kolesterol dalam tubuh berlebih dan terjadi dalam waktu lama, kolesterol akan menumpuk di dinding arteri atau dikenal sebagai aterosklerosis yang dapat menyebabkan penyakit serebrovaskular (stroke), jantung koroner, dan penyakit pembuluh darah perifer dan batu empedu. ${ }^{5}$ Tingginya kolesterol dan hipertensi adalah dua kriteria dari sindroma metabolik yang merupakan faktor risiko terjadinya penyakit kadiovaskuler. Berdasarkan NCEP ATP III dan International Diabetes Foundation (IDF) memiliki kriteria tersendiri dalam menentukan sindroma metabolik yaitu setidaknya ada tiga dari lima kriteria yang tersedia. Kriteria tersebut adalah peningkatan lingkar perut, peningkatan trigliserida, penurunan HDL-kolesterol, peningkatan tekanan darah, dan peningkatan glukosa dalam darah. Penyakit sindroma metabolik pun merupakan faktor risiko terjadinya penyakit kadiovaskuler seperti serangan jantung, stroke, gagal jantung dan kegagalan organ lain seperti penyakit ginjal. ${ }^{6}$

Jatinangor merupakan kawasan perkebunan yang beralih fungsi menjadi kawasan pendidikan tinggijatinangor(KPTJ) padatahun 1989. Relokasi universitas dari bandung ke jatinangor selain berdampak positif terhadap wilayah Bandung yaitu mengurangi kecepatan pertumbuhan populasi di Bandung, namun memiliki dampak negatif terhadap wilayah Jatinangor. Sekarang jatinangor dijadikan sebagai kawasan pendidikan tinggi, jatinangor juga dijadikan sebagai perkembangan aktivitas bisnis dan industri. Tahun 1989 pemerintah mengeluarkan surat keputusan No.583, pembangunan fisik utama perkotaan telah terjadi di daerah ini termasuk perubahan penggunaan lahan dari rural ke urban, perubahan kecamatan dan peningkatan aktivitas urban. Jatinangor mengalami perkembangan yang pesat, perkembangan wilayah ini direfleksikan oleh dua perubahan, yaitu perubahan fisik ditandai dengan peningkatan populasi dan transformasi sosioekonomik yang ditandai dengan banyaknya restauran-restauran, asrama ataupun hal yang lainnya yang semakin memudahkan penduduknya. ${ }^{7}$

Peningkatan urbanisasi, perubahan sosioekonomik serta kultural akan mempengaruhi gaya hidup seseorang. Sekarang ini Jatinangor telah menjadi tempat urbanisasi yang sebagian besar orang lebih senang hidup sedentari, mengkonsumsi makanan cepat saji yang berlemak tinggi, stress, merokok dan mengkonsumsi alkohol, yang merupakan faktor risiko terjadinya hipertensi dan penyakit kardiovaskuler., ${ }^{4} 7$ 
Penelitian telaah sistematik yang telah dilakukan oleh Reilly J.J. dan Kelly J. pada Januari 2002 sampai pertengahan Juni 2010 menyatakan bahwa obesitas berhubungan dengan peningkatan risiko terkena penyakit yang berhubungan dengan tekanan pembuluh darah seperti hipertensi, stroke dan penyakit jantung iskemik. ${ }^{8}$ Berdasarkan prevalensi kejadian hipertensi yang telah diketahui dan dilihat dari data-data di atas terdapat kecenderungan yang kuat antara kadar kolesterol total dengan hipertensi di Jatinangor, oleh karena itu dibutuhkan penelitian mengenai hubungan antara kadar kolesterol total dengan tekanan darah pada masyarakat Jatinangor.

\section{Metode}

Penelitian ini merupakan observasional analitik korelasional dengan rancangan potong lintang untuk mengetahui hubungan kadar kolesterol total dengan tekanan darah sistolik (TDS) dan tekanan darah diastolik (TDD) pada masyarakat Jatinangor. Penentuan jumlah sampel dalam penelitian ini menggunakan rumus analitik korelasi sebesar 107 subjek, hasil penelitian diperoleh besar sampel minimal yang dibutuhkan adalah 79, dengan pemilihan taraf signifikansi alpha $(\alpha)=5 \%$ dan beta $(\beta)=5 \%$ serta koefisien korelasi sistolik $(\mathrm{r} 1)=0,39$ dan koefisien korelasi diastolik $(\mathrm{r} 2)=0,43$. Subjek penelitian ini dipilih secara simple random sampling dari data sekunder penelitian "Epidemiologi Hipertensi dan Albuminuria di Jatinangor pada tahun 2014". Penelitian ini dilakukan pada bulan AgustusNovember 2016 dengan mengikutsertakan kriteria inklusi yaitu responden berusia lebih dari 18 tahun yang berdomisili di tiga desa yaitu Cilayung, Hegarmanah, dan Cipacing. Data yang lengkap yang berisi data yang mencantumkan keterangan demografi baik nama, tempat tinggal, usia serta pendidikan, data yang mencantumkan hasil pengukuran tekanan darah dan hasil pemeriksaan kolesterol. Kriteria eksklusi penelitian ini adalah responden yang sedang meminum obat hipertensi, responden yang memiliki penyakit penyerta seperti stroke.

Variabel yang dinilai dalam penelitian ini adalah kadar kolesterol total sebagai variabel bebas, tekanan darah sistolik (TDS) dan tekanan darah diastolik (TDD) sebagai variabel terikat. Penelitian ini juga menilai karakteristik subjek yang terdiri dari Jenis kelamin (laki-laki dan perempuan), usia (18-29, 30-39, 40-49, 50-59, 60-69 dan $\geq 70$ ) dan tingkat pendidikan (dasar, menengah dan perguruan tinggi).

Penelitian ini telah mendapatkan persetujuan etik dari Komite Etik Penelitian Kesehatan
Fakultas Kedokteran Universitas Padjdjaran. Instrumen penelitian ini menggunakan data sekunder dari penelitian utama mengenai "Epidemiologi Hipertensi dan Albuminuria di Jatinangor pada tahun 2014" dalam naungan pusat studi kesehatan dan kebugaran komunitas. Data yang terkumpul dianalisis dengan menggunakan suatu program pemprosesan data statistik dengan melakukan uji secara deskriptif terlebih dahulu untuk mengetahui gambaran dari populasi subjek penelitian, selanjutnya dilakukan uji secara analitik yaitu uji normalitas dengan menggunakan Kolmogorov-Smirnov untuk mengetahui distribusi dari berbagai variabel. Untuk menganalisis hubungan kadar kolesterol total dengan TDS dam TDD digunakan uji statistik korelasi Rank Spearman. Signifikansi uji ditentukan berdasarkan nilai-p $<0,05$. Data hasil analisis selanjutnya disajikan dalam bentuk tabel dan gambar.

\section{Hasil}

Tabel 1 Karakteristik Subjek Penelitian $(\mathbf{n}=107)$

\begin{tabular}{cccc}
\hline No. & Karakteristik & Jumlah & Persentase \\
\hline 1 & Jenis Kelamin & & \\
Laki-laki & 32 & 29,9 \\
2 & Perempuan & 75 & 70,1 \\
& Usia (tahun) & & \\
& $18-29$ & 2 & 1,9 \\
$30-39$ & 16 & 15 \\
$40-49$ & 8 & 7,5 \\
$50-59$ & 18 & 16,8 \\
$60-69$ & 32 & 29,9 \\
$\geq 70$ & 31 & 29 \\
& Median & 62 & \\
Rentang & $23-82$ & \\
& Tingkat Pendidikan & & \\
& Dasar & 84 & 78,5 \\
& Menengah & 20 & 18,7 \\
& Tinggi & 3 & 2,8 \\
\hline & &
\end{tabular}

Berdasarkan data yang ditunjukkan pada tabel 1 , seluruh subjek penelitian pada karaktetristik jenis kelamin didominasi oleh jenis kelamin perempuan, sedangkan pada karakteristik usia disominasioleh usia diatas 50 . Berdasarkan tingkat pendidikan subjek, mayoritas berpendidikan pendidikan dasar. 
Tabel 2 menunjukkan distribusi statistik dari berbagai variabel. Pada variabel Tekanan darah sistolik (TDS) menunjukkan tekanan darah yang meningkat dan sudah tergolong hipertensi derajat 1. Sedangkan pada tekanan darah diastolik (TDD) menunjukkan tekanan darah yang meningkat yang termasuk klasifikasi prehipertensi. Kadar kolesterol total tergolong normal, walaupun jika dilihat dari nilai rentang kadar kolesterol total sebagian subjek ada yang memiliki kadar kolesterol total yang tinggi. Hasil uji normalitas data menunjukkan variabel TDS berdistribusi normal, sedangkan untuk variabel TDD dan kadar kolesterol total tidak berdistribusi normal $(\mathrm{p}<0,05)$.

Tabel 3 menunjukkan deskriptif statistik dari berbagai variabel berdasarkan usia. Pada seluruh subjek penelitian terdapat peningkatan nilaitengah TDS pada usia 50-59 tahun yang menunjukkan tekanan darah yang tinggi dan termasuk kedalam klasifikasi hipertensi derajat 1 , namun pada usia 40-49 tahun juga sudah menunjukkan peningkatan tekanan darah yang termasuk kedalam klasifikasi prehipertensi. Sedangkan pada TDD terdapat peningkatan nilai tengah pada usia $\geq 50$ tahun yang termasuk kedalam tekanan darah prehipertensi. Kadar kolesterol total terlihat normal meskipun terdapat sebagian populasi dengan kadar kolesterol yang meningkat.

Tabel 4 menunjukkan hubungan kadar kolesterol total dengan tekanan darah baik TDS ataupun TDD. Hubungan antara kadar kolesterol total dengan TDS menunjukkan adanya korelasi yang positif berdasarkan nilai $p=0,004 \quad(p<0,05)$, meskipun korelasi yang terbentuk adalah korelasi yang lemah. Sedangkan hubungan antara kadar kolesterol total dengan TDD menunjukkan tidak adanya hubungan antara keduanya, karena nilai $\mathrm{P}=0,136(\mathrm{p}>0,05)$.

Tabel 2 Deskriptif Statistik dari Pengukuran Tekanan Darah dan Kadar Kolesterol Total

\begin{tabular}{llccc}
\hline \multirow{2}{*}{ No } & \multicolumn{1}{c}{ Variabel } & \multicolumn{2}{c}{ Ukuran Statistik } & \multirow{2}{*}{ Uji Normalitas Data (Nilai p)* } \\
\cline { 3 - 4 } & & Median & Rentang & \\
\hline 1 & Tekanan Darah Sistolik (mmHg) & 144 & $98-224$ & 0,059 \\
2 & Tekanan Darah Diastolik (mmHg) & 85 & $58-139$ & 0,011 \\
3 & Kolesterol (mg/dL) & 189 & $110-310$ & 0,012 \\
\hline \multirow{2}{*}{)} & Berdasarkan Uji Kolmogorof-Smirnov & &
\end{tabular}

Tabel 3 Tekanan Darah Sistolik dan Diastolik dan Kadar Kolesterol Total berdasarkan Usia

\begin{tabular}{ccccccccc}
\hline \multirow{2}{*}{ No } & \multirow{2}{*}{ Usia (tahun) } & \multirow{n}{*}{} & \multicolumn{2}{c}{ Sistolik } & \multicolumn{2}{c}{ Diastolik } & \multicolumn{2}{c}{ Kolesterol Total } \\
\cline { 3 - 8 } & & Median & Rentang & Median & Rentang & Median & Rentang \\
\hline 1 & $18-29$ & 2 & 117 & $101-133$ & 79 & $71-87$ & 172,5 & $162-183$ \\
2 & $30-39$ & 16 & 115 & $106-143$ & 74 & $66-102$ & 145 & $110-198$ \\
3 & $40-49$ & 8 & 132 & $98-153$ & 81 & $68-104$ & 188,5 & $134-227$ \\
4 & $50-59$ & 18 & 149,5 & $113-206$ & 87,5 & $59-115$ & 185 & $111-310$ \\
5 & $60-69$ & 32 & 147 & $103-207$ & 87 & $58-129$ & 199,5 & $118-280$ \\
6 & $\geq 70$ & 31 & 161 & $120-224$ & 88 & $63-139$ & 198 & $132-277$ \\
\hline
\end{tabular}

Tabel 4 Hubungan Kadar Kolesterol Total dengan Tekanan Darah

\begin{tabular}{llcc}
\hline No & \multicolumn{1}{c}{ Korelasi } & R & Nilai-p \\
\hline 1 & $\begin{array}{l}\text { Kadar kolesterol total dengan tekanan darah } \\
\text { sistolik }\end{array}$ & 0,279 & 0,004 \\
2 & $\begin{array}{l}\text { Kadar kolesterol total dengan tekanan darah } \\
\text { diastolik }\end{array}$ & 0,145 & 0,136 \\
\hline
\end{tabular}

Keterangan $\mathrm{r}=$ koefisien korelasi Rank Spearman 

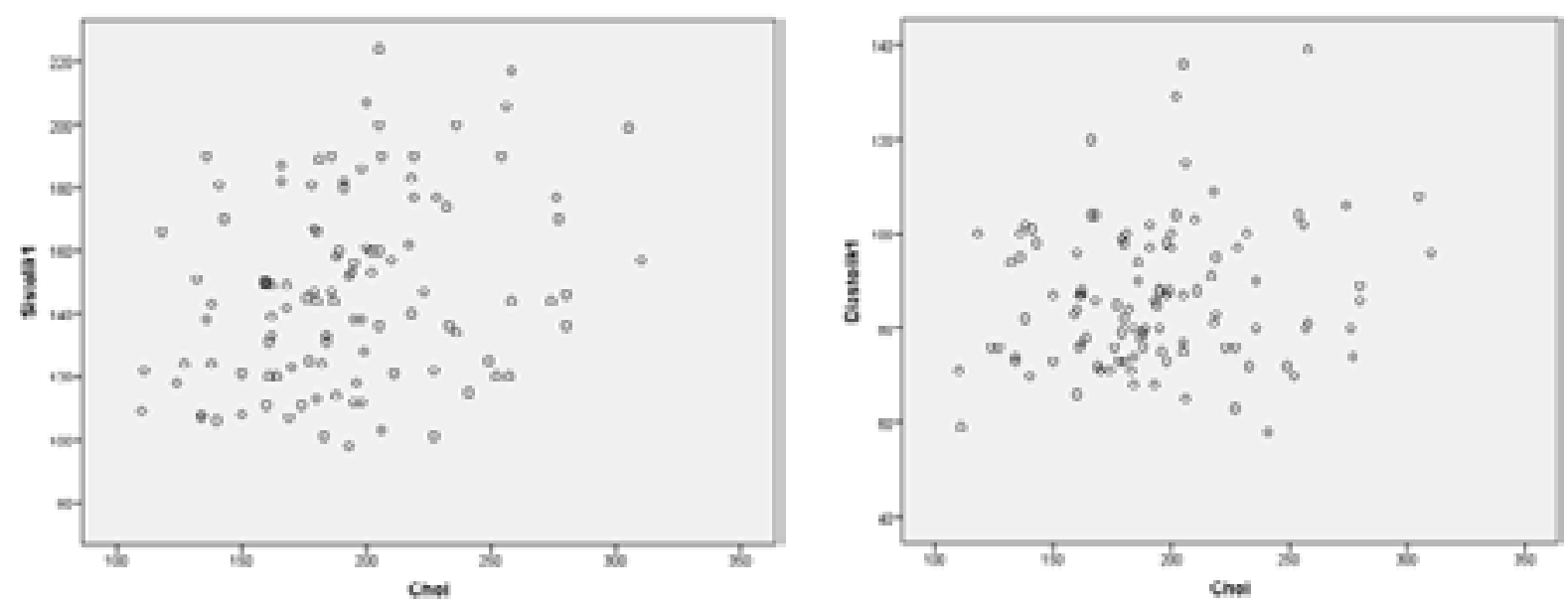

Gambar 1 Hubungan antara Kadar Kolesterol Total dengan Tekanan Darah Sistolik dan Tekanan Darah Diastolik bersifat tidak linear

\section{Pembahasan}

Penelitian ini melihat hubungan antara kadar kolesterol total dengan tekanan darah pada masyarakat Jatinangor. Berdasarkan data karakterisktik subjek, terlihat dominasi subjek perempuan, hal ini disebabkan karena waktu pengambilan data primer pada penelitian "Epidemiologi Hipertensi dan Albuminuria di Jatinangor pada tahun 2014" dilakukan pada saat jam kerja sehingga subjek laki-laki yang berada di rumah menjadi sedikit. Usia subjek penelitian didominasi usia $>60$ tahun, ini dikarenakan pada usia tersebut sudah tidak lagi bekerja ataupun jika bekerja hanya di sekeliling rumahnya saja dikarenakan kondisi fisik yang sudah mulai turun. Tingkat pendidikan akhir subjek paling banyak adalah tingkat SD, hanya sedikit yang melanjutkan pendidikan hingga ke SMA ataupun perguruan tinggi. Dengan demikian, dapat dikategorikan tingkat pendidikan subjek adalah rendah.

Hasil dari penelitian ini diperoleh bahwa adanya peningkatan tekanan darah sesuai dengan bertambahnya usia. Keadaan prehipertensi dan hipertensi pada TDS terlihat pada usia $\geq 40$ tahun dan $\geq 50$ tahun secara berurutan. Sedangkan pada TDD terlihat keadaan prehipertensi dan hipertensi pada usia $\geq 50$ tahun dan usia $\geq 70$ tahun secara berurutan. Berdasarkan analisis riset kesehatan dasar kementrian kesehatan Indonesia pada tahun 2013, prevalensi hipertensi meningkat seiring dengan bertambahnya usia. ${ }^{1}$ Umumnya hipertensi terjadi pada usia $>50$ tahun. Adanya peningkatan usia akan secara progresif terjadi penurunan sifat visco-elastis dari pembuluh darah yang menyebabkan peningkatan total resistensi pembuluh darah. Oleh sebab itu akan terjadi peningkatan curah jantung, aliran darah renal, dan aktivitas renin dalam plasma yang akan mengakibatkan penurunan kemampuan ginjal untuk mengekskresikan kelebihan garam secara efesien, ini akan menyebabkan terjadinya hipertensi. Faktor lain yang mempengaruhi patofisiologi hipertensi dengan peningkatan usia antara lain yaitu adanya penurunan sensitivitas baroreseptor, peningkatan secara responsif stimulasi sistem saraf simpatik, perubahan metabolisme sodium dalam ginjal dan adanya perubahan hubungan renin-aldosteron. ${ }^{5,9}$

Kadar kolesterol total merupakan prekursor asam empedu dan hormon steroid, vitamin D, serta unsur penting dalam membran sel yang penting dalam menjaga permeabilitas dan kestabilan jaringan membran. Kolesterol banyak terdapat dalam produk berbahan dasar hewani seperti kuning telur, daging, hati dan otak. Jika kolesterol berlebih atau hiperkolesterolemia dan terjadi dalam waktu lama, kolesterol akan menumpuk di dinding arteri yang menurunkan permeabilitas pembuluh darah yang dapat meningkatkan tekanan pembuluh darah dan dapat menyebabkan terjadinya hipertensi serta penyakit serebrovaskular (stroke) ataupun kardiovascular. ${ }^{5,9,10,11}$

Secara teori, tekanan darah dapat dipengaruhi oleh banyak faktor atau multifaktorial, baik faktor perilaku seperti aktivitas fisik yang kurang dan konsumsi makanan yang banyak mengandung garam dan lemak, faktor sosioekonomi seperti urbanisasi, usia, pendidikan dan pendapatan, serta faktor genetik yang dapat mempengaruhi terjadinya hipertensi. ${ }^{1,5,12}$ Hipertensi pada orang yang memiliki hiperkolesterolemia dengan obesitas diperkirakan terjadi akibat adanya 
peningkatan sekresi leptin dan adipokin yang akan menyebabkan aktivitas dari berbagai faktor inflamasi (TNF- $\alpha$ /tumor necrosis factor, IL-6/ interleukin-6, IL-1/interleukin-1, kemokin dan makrofag) yang menyebabkan jejas endotel (endothelial injury) yang membuat makrofag teraktivasi sehingga terdeposisi dalam pembuluh darah, yang akan menyempitkan lumen pembuluh darah serta meningkatkan resistensi vaskuler perifer. Kolesterol yang berlebih dalam tubuh akan menyebabkan adanya penurunan adiponektin yang menyebabkan peningkatan resistensi insulin. Resistensi insulin ini menyebabkan hiperinsulinemia yang menyebabkan agregasi platelet dan peningkatan aktivasi sistem saraf simpatik yang mengekibatkan peningkatan katekolamin dan hiperfiltrasi glomerulus sehingga terjadi retensi sodium $(\mathrm{Na}+)$ yang mengakibatkan peningkatan volume darah, peningkatan proliferasi otot polos dan produksi hormon norepineprin yang menyebabkan meningkatnya curah jantung. Adanya peningkatan resistensi perifer dan curah jantung akan menyebabkan terjadinya hipertensi. ${ }^{13-18}$

Dari hasil penelitian yang dilakukan, diperoleh bahwa adanya hubungan antara kadar kolesterol total dengan tekanan darah sistolik (TDS) sebesar $p=0,004$ dengan $r=0,279$ yang menunjukkan kekuatan korelasi lemah. Penelitian ini sesuai dengan penelitian sebelumnya di puskesmas kelurahan Joglo-II, Jakarta (Indonesia), yang menunjukkan hubungan antara kadar kolesterol total dengan tekanan darah sistolik $(r=0,39$; nilai $\mathrm{p}=0,005) \cdot{ }^{19}$ Hubungan antara kadar kolesterol dan tekanan darah juga diteliti di Oslo, Nowegia diantara sampel laki-laki yang berusia 20-49 tahun. Hasil penelitian menunjukkan korelasi lemah $(\mathrm{r}=0,16$; nilai $\mathrm{p}<0,01)$ antara tekanan darah dan kolesterol serta didapatkan pada usia 40 - 49 tahun perbedaan kolesterol antara tekanan diastolik $<70 \mathrm{mmHg}$ dan $\geq 110 \mathrm{mmHg}$ adalah $27,4 \mathrm{mg} / \mathrm{dL} .{ }^{20}$ Namun pada penelitian ini menunjukkan tidak adanya hubungan antara kadar kolesterol total dengan kejadian hipertensi pada tekanan darah diastolik (TDD) dengan nilai $\mathrm{p}=$ 0,136 dan $r=0,145$; hasil ini tidak sesuai dengan hasil penelitian sebelumnya yang telah dilakukan di Jakarta yang menunjukkan adanya hubungan antara kadar kolesterol total dengan tekanan darah diastolik $(\mathrm{r}=0,43$; nilai $\mathrm{p}=0,002){ }^{19}$

Hasil penelitian ini memiliki asosiasi searah dengan kekuatan hubungan yang lemah untuk tekanan darah sistolik dan tidak ada hubungan untuk tekanan darah diastolik, ini sesuai dengan teori siklus jantung. Tekanan sistolik mengukur tekanan dalam arteri saat jantung berdetak atau ketika otot ventrikel jantung kontraksi dimana darah mengalir dari ventrikel melalui pembuluh darah menuju paru-paru dan seluruh tubuh. Tekanan diastolik mengukur tekanan dalam arteri antara denyut jantung atau ketika otot ventrikel jantung relaksasi di antara kontraksi dan saat jantung terisi darah. Kemungkinan adanya peningkatan tekanan darah sistolik disebabkan karena adanya kekakuan atau penurunan kelenturan arteri besar atau terbentuknya ateroma, namun ini tidak terjadi pada tekanan darah diastolik..$^{9,19}$

Keterbatasan dalam penelitian ini adalah kondisi data yang merupakan data sekunder, sehingga variabel yang tersedia sudah pasti dan sulit untuk dikembangkan, hal ini menyebabkan eksplorasi penelitian yang terbatas. Penelitian ini tidak menghiraukan variabel perancu sehingga tidak diketahui faktor mana saja yang mempengaruhi kadar kolesterol total dan tekanan darah, serta tidak diketahui nilai perbandingan variabel yang dominan yang mempengaruhi kadar kolesterol total dan tekanan darah. Penelitian ini menggunakan studi potong lintang sehingga hasilnya kurang memperlihatkan keterkaitan antar variabelnya.

Dari hasil penelitian dan pembahasan dapat disimpulkan kadar kolesterol total berhubungan dengan tekanan darah sistolik dengan nilai korelasi yang lemah, semakin tinggi kadar kolesterol total hanya sedikit memengaruhi peningkatkan tekanan darah sistolik. Sedangkan hubungan kadar kolesterol total dengan tekanan darah diastolik tidak menunjukkan hubungan yang bermakna.

Saran untuk penelitian selanjutnya adalah penelitian dapat dilakukan pada populasi yang lebih luas, sehingga dapat mewakili semua populasi usia. Selain itu, bisa dilakukan penelitian lebih lanjut, penelitian selanjutnya dapat dilakukan dengan mempertimbangkan faktorfaktor perancu yang mungkin memengaruhi.

\section{Daftar Pustaka}

1. Badan Penelitian dan Pengembangan Kesehatan Kementrian Kesehatan Indonesia Tahun 2013 (Riset Kesehatan Dasar). Kementrian Kesehatan RI; 2013.

2. Faris Y Fihaya YS, Hadyana Sukandar et al. Prevalence of Hypertension and Its Complications in Jatinangor 2014. J Hypertension. 2015;33. Available from: http://journals.lww.com/.

3. Leung Ong K, M.Y. Cheung $B$ et al. Prevalence, Awareness, Treatment, and Control of Hypertension Among United States Adults 1999-2004. Journal of American Heart Association. 2007;49:69-75. 
Available from: http://www.hypertensionaha. org

4. A. Kronmal R, L. McClelland R, Detrano R, Shea S, A. Lima J, dkk. Risk Factors for the Progression of Coronary Artery Calcification in Asymptomatic Subjects Results From the Multi-Ethnic Study of Atherosclerosis (MESA). Journal of American Heart Association. 2007;115:2722-2730. Available from: http:/www.circulationaha.org

5. Peter L. Gross, Molly Jacob, Peter A. Mayes et al. Harper's Illustrated Biochemistry. 30th ed. 2015. p. 211-276.

6. Alberti K, H. Eckel R, M. Grundy S, Z. Zimmet P, I. Cleeman J, dkk. Harmonizing the Metabolic Syndrome. Journal of American Heart Association. 2009;120:1640-1645. Available from: http://circ.ahajournals.org

7. Salim W. Development of the Jatinangor University Area, Indonesia. In: wim Wiewel DCP, editor. Global Universities and Urban Development Case Studies and Analysis. Sumedang; 2015.

8. Reilly JJ, Kelly J. Long-term impact of overweight and obesity in childhood and adolescence on morbidity and premature mortality in adulthood: systematic review. Int $\mathrm{J}$ Obes (Lond). Nature Publishing Group;2011;35(July 2010):891-8. Available from: http://dx.doi.org/10.1038/ijo.2010.222

9. Hall JE, Guyton AC. Circulation. Guyton dan Hall Buku Ajar Fisiologi kedokteran, Edisi 12. 2011.

10. John Chapman M, N. Ginsberg H, Amarenco $\mathrm{P}$, Andreotti F, Bore J, dkk. Triglyceriderich lipoproteins and high-density lipoprotein cholesterol in patients at high risk of cardiovascular disease: evidence and guidance for management. European Heart Journal. 2011; 32, 1345-1361.

11. Barter P, M. Gotto A, C. LaRosa J, Maroni J, Szarek M, dkk. HDL Cholesterol, Very Low Levels of LDL Cholesterol, and
Cardiovascular Events. The New England Journal of Medicine. 2007;357:1301-10. Available from: www. nejm.org

12. Nur Syahrini E, Setyawan Susanto H, Udiyono A. Faktor-Faktor RisikoHipertensi Primer di Puskesmas Tlogosari Kulon Kota Semarang. Jurnal Kesehatan Masyarakat. 2012;1(2):315-325.

13. J. Adrogué H, and E. Madias N. Sodium and Potassium in the Pathogenesis of Hypertension. The New England Journal of Medicine. 2007; 356:1966-1978.

14. Hussain a, Hydrie MZI. Review Article : Type 2 Diabetes and obesity: A review strongly implicated in the development of insulin. J Diabetol. 2010;(June):1-7.

15. Guo S. Insulin signaling, resistance, and metabolic syndrome: Insights from mouse models into disease mechanisms. J Endocrinol. 2014;220(2).

16. Huang P. L. A comprehensive definition for metabolic syndrome. Dis Model Mech. 2009;2(5-6):231-7.

17. Rask-Madsen C, Kahn CR. Tissue-specific insulin signaling, metabolic syndrome, and cardiovascular disease. Arterioscler Thromb Vasc Biol. 2012;32(9):2052-9.

18. J. Ryan M. An Update on Immune System Activation in the Pathogenesis of Hypertension. Journal of American Heart Association. 2013;62:226-230.

19. Margarita Y, Andi P, Erwina M, dkk. Kadar Kolesterol Total dan Tekanan Darah Orang Dewasa Indonesia. J Kesehat Masy Nas. 2013;8(2):79-84.

20. Hjerman I, Helgeland A, Holme I, Larsen P. The association between blood pressure and serum cholesterol in healthy men: the Oslo study. J Epidemiol Comm Health. 1978; 32: 117-23. Available from: http://www.ncbi. nlm.nih.gov/pmc/articles/PMC1060929/pdf/ jepicomh2000 02-1046.pdf. 